BMC

Microbiology

Role of EscU auto-cleavage in promoting type III effector translocation into host cells by enteropathogenic Escherichia coli

Thomassin et al. 


\title{
Role of EscU auto-cleavage in promoting type III effector translocation into host cells by enteropathogenic Escherichia coli
}

\author{
Jenny-Lee Thomassin ${ }^{1,2}$, Xiang He ${ }^{1}$ and Nikhil A Thomas ${ }^{1 *}$
}

\begin{abstract}
Background: Type III secretion systems (T3SS) of bacterial pathogens coordinate effector protein injection into eukaryotic cells. The YscU/FlhB group of proteins comprises members associated with T3SS which undergo a specific auto-cleavage event at a conserved NPTH amino acid sequence. The crystal structure of the C-terminal portion of EscU from enteropathogenic Escherichia coli (EPEC) suggests this auto-cleaving protein provides an interface for substrate interactions involved in type III secretion events.

Results: We demonstrate EscU must be auto-cleaved for bacteria to efficiently deliver type III effectors into infected cells. A non-cleaving EscU(N262A) variant supported very low levels of in vitro effector secretion. These effector proteins were not able to support EPEC infection of cultured HeLa cells. In contrast, EscU(P263A) was demonstrated to be partially auto-cleaved and moderately restored effector translocation and functionality during EPEC infection, revealing an intermediate phenotype. EscU auto-cleavage was not required for inner membrane association of the T3SS ATPase EscN or the ring forming protein EscJ. In contrast, in the absence of EscU autocleavage, inner membrane association of the multicargo type III secretion chaperone CesT was altered suggesting that $\mathrm{EsCU}$ auto-cleavage supports docking of chaperone-effector complexes at the inner membrane. In support of this interpretation, evidence of novel effector protein breakdown products in secretion assays were linked to the non-cleaved status of EscU(N262A).

Conclusions: These data provide new insight into the role of EsCU auto-cleavage in EPEC. The experimental data suggests that $\mathrm{EsCU}$ auto-cleavage results in a suitable binding interface at the inner membrane that accommodates protein complexes during type III secretion events. The results also demonstrate that altered EPEC genetic backgrounds that display intermediate levels of effector secretion and translocation can be isolated and studied. These genetic backgrounds should be valuable in deciphering sequential and temporal events involved in EPEC type III secretion.
\end{abstract}

\section{Background}

Type III secretion systems (T3SS) of bacterial pathogens translocate effector proteins into infected cells resulting in a variety of modulations and disruptive actions to host cellular processes. Examples include preventing phagocytosis [1-4], altering Rho signalling [5,6], subverting intracellular membrane trafficking [7-10] and manipulating innate immune responses [11-16].

\footnotetext{
* Correspondence: n.thomas@dal.ca

'Department of Microbiology and Immunology, Dalhousie University, 5850 College Street, P.O. Box 15000, Halifax, Nova Scotia, B3H 4R2 Canada Full list of author information is available at the end of the article
}

T3SS are composed of at least 10 conserved proteins [17] some of which are present in multiple copies. Specific protein components form an export apparatus within the inner membrane. A needle complex is formed using the general secretory pathway (sec system) for some of the 'ring' forming components located in the inner and outer bacterial membrane. Cryo-electron microscopy studies of 'needle complexes' isolated from Salmonella enterica serovar Typhimurium report a needle-like appendage with a central conduit of approximately 28 Angstroms $[18,19]$. For EPEC, 'intact' needle complexes have been difficult to isolate [20] and therefore detailed structural information is lacking. A novel 
difference for EPEC needle complexes is the presence of a polymeric EspA protein filament on top of a basal needle complex [21]. The complete T3SS, composed of the export apparatus and needle complex, then secretes pore and filament forming proteins (EspA, EspB and EspD translocator proteins [22]) and eventually effector proteins, the latter of which are rapidly injected directly into host cells during infection.

A conserved inner membrane protein found in all T3SS is YscU (FlhB homologues). This group of proteins has been the focus of considerable studies owing to an interesting proteolytic activity. Specifically, FlhB/YscU proteins undergo a post-translational intein-like autocleavage event at a conserved NPTH amino acid sequence, the result of which leads to proper secretion system functionality $[23,24]$. Auto-cleavage occurs between the asparagine and proline residues with the resulting polypeptides remaining tightly associated within the bacterial cell [25]. In Enteropathogenic E. coli (EPEC), the auto-cleavage mechanism for its YscU homologue, EscU, was elucidated through protein crystallization studies [26]. The reaction mechanism occurs at a type II $\beta$-turn and produces a conformational change in EscU, spatially moving the histidine within the NPTH region $180^{\circ}$. It was proposed that this striking conformational change provides a new interface for protein interactions that are required for efficient secretion [26]. In support of this interpretation, a non-cleaving EscU variant (e.g. N262A) did not support type III protein secretion [26]. A soluble C-terminal EscU(P263A) variant also remained un-cleaved in protein crystals, although it was suggested that the reaction mechanism could still occur at elevated $\mathrm{pH}$ or with slow kinetics. The protein structures of other EscU homologues (YscU, Spa40) have shown similar auto-cleavage mechanisms [27-29] indicating a remarkable functional importance for this proteolytic event in secretion events. In all cases, the YscU homologue is an essential component of the respective secretory apparatus, however, there is considerable variability amongst bacteria in the secretory phenotypes that are associated with $\mathrm{YscU}$ or FlhB auto-cleavage. In the case of $Y$. enterocolitica, noncleaving YscU variants were found to support secretion of type III effector proteins but not translocator proteins suggesting that $\mathrm{YscU}$ auto-cleavage serves to recognize translocators for type III secretion in this pathogen [30]. In two other Yersinia species, $Y$. pestis and $Y$. pseudotuberculosis, non-cleaving YscU forms showed dramatic reduction of effector and translocator protein secretion compared to the respective wild type strains suggesting a modulating role for the $\mathrm{YscU}$ auto-cleavage event $[24,31]$. In the plant pathogen Xanthomonas campestris, the $\mathrm{C}$-terminal region of $\mathrm{HrcU}$ was demonstrated to interact with the putative substrate switching protein
$\mathrm{HpaC}$, leading to effector secretion. With respect to flagellum biogenesis, an uncleaved form of FlhB (a YscU homologue) was demonstrated to selectively export only rod/hook-type protein substrates but not filament type substrates [32]. This observation is in line with a modulatory or substrate switching role for FlhB auto-cleavage. From all these studies, it appears that the context of the YscU homologue and its interactions with other secretory components influence T3SS function. It remains that auto-cleavage function is likely contextual and may have specific secretory consequences in different bacteria.

In this study, we provide experimental evidence that EscU auto-cleavage in EPEC promotes effector protein translocation into host cells during infection. In the absence of EscU auto-cleavage, very low levels of effector proteins were secreted as non-functional and abnormal forms. EscU auto-cleavage also promoted efficient membrane association of the multicargo type III chaperone CesT, which has implications for effector delivery into cells during infection.

\section{Results}

Uncleaved forms of EscU support low levels of translocator and effector protein secretion into culture supernatants

Based on previous protein crystallography studies [26], we generated three recombinant plasmids that encode auto-cleaved or uncleaved histidine tagged forms of EscU (39 kDa) (see Materials and Methods). EscU-HIS (pJLT21), EscU(N262A)-HIS (pJLT22) and EscU (P263A)-HIS (pJLT23) were created for initial characterization studies. Unlike Shigella species where Congo Red is used to 'induce' in vitro type III secretion [33], culturing EPEC in DMEM 'induces' type III secretion $[34,35]$. After culturing for 6 hours in DMEM, whole cell lysates and culture supernatants were collected from $\Delta e s c U$ strains harbouring pJLT21, pJLT22 and pJLT23. EscU auto-cleavage at the NPTH catalytic site is predicted to produce an 89 amino acid C-terminal product of $10.3 \mathrm{kDa}$. Immunoblotting whole cell lysates indicated that EscU-HIS was auto-cleaved due to the detection of an approximately $10 \mathrm{kDa}$ species with anti-HIS antibodies (Figure 1A). A longer immunoblot exposure did not reveal any uncleaved EscU (39 kDa) suggesting complete auto-cleavage. In contrast, $\Delta e s c U$ whole cell lysates containing EscU(N262A) or EscU(P263A) produced a 39 $\mathrm{kDa}$ species detected by anti-HIS antibodies, a molecular weight consistent with uncleaved (intact) EscU.

To further characterize these strains, the respective culture supernatant fractions were evaluated. Under these growth conditions, four predominant protein species are routinely detected in secretion fractions and have been identified using protein micro-sequencing 


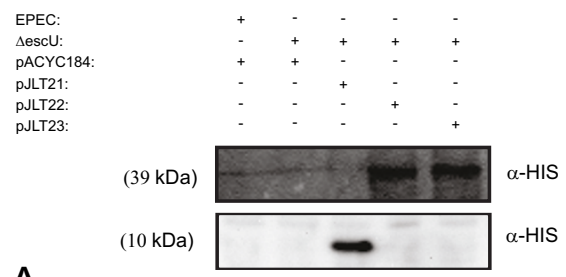

A
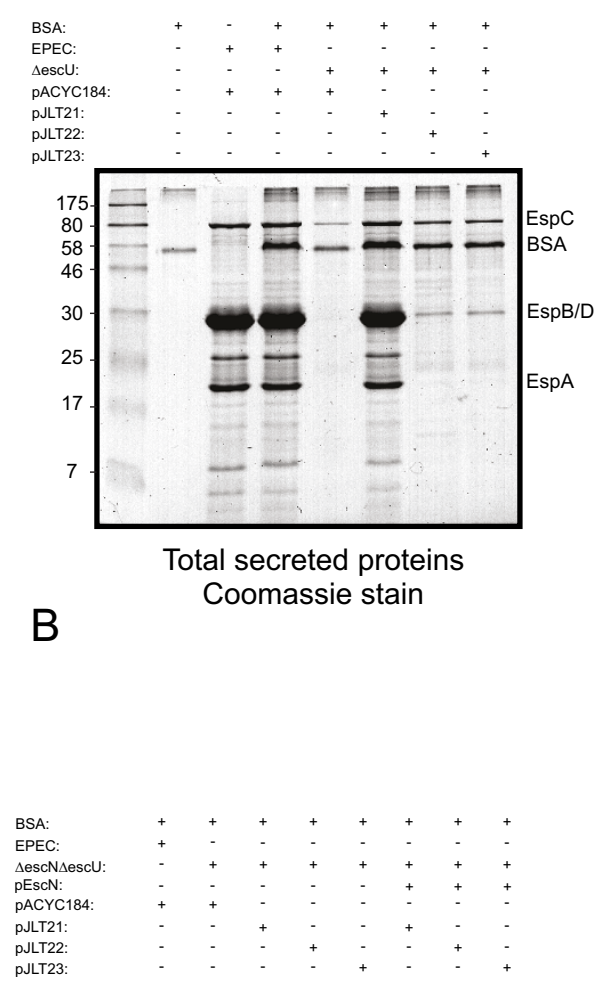

pJLT23:

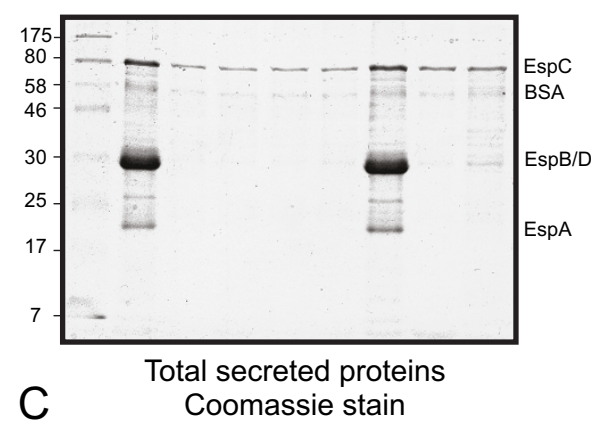

secreted

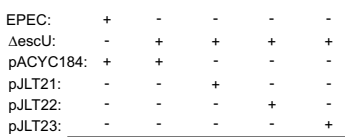

p)

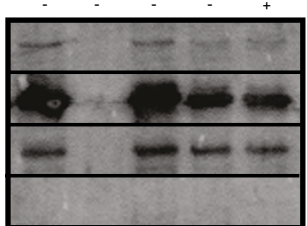

$\alpha$-EspA $(20 \mathrm{kDa})$

$\alpha$-EspB (30 kDa)

$\alpha$-Tir $\quad(62 \mathrm{kDa})$

$\alpha$-DnaK (70 kDa)

cell lysate

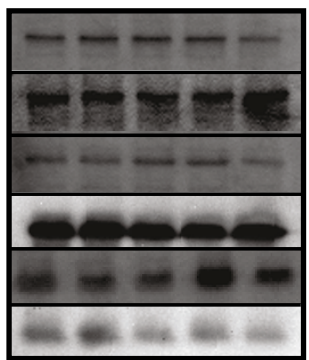

$\alpha$-EspA (20 kDa)

$\alpha$-EspB (30 kDa)

$\alpha$-Tir $\quad(62 \mathrm{kDa})$

$\alpha$-DnaK (70 kDa)

$\alpha$-EscJ (20 kDa)

$\alpha$-EscC (50 kDa)

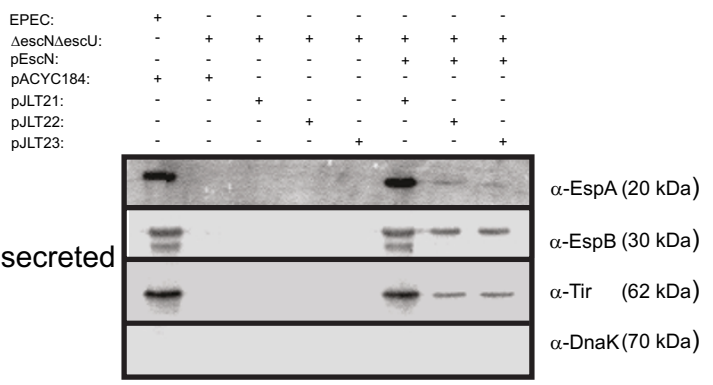

Figure 1 Efficient translocon and effector secretion is dependent on EscU auto-cleavage. (A): Immunoblot demonstrating EscU variant cleavage status within whole cell lysates. The blots were imaged separately to get representative signals for the auto-cleavage products. A longer exposure was used for the $39 \mathrm{kDa}$ protein species. (B) Left: trans-complementation of $\triangle$ esc $\mathrm{U}$ with pJLT21 restores EspA ( 20 kDa), EspB and $\mathrm{EspD}$ (co-migrate $\sim 30 \mathrm{kDa}$ ) secretion to wild type levels (the identity of these dominant protein species has been previously determined using protein sequencing [36], and here by immunoblotting [right panel]). EspC is an abundant type 5 secreted protein. Bovine serum albumin (BSA) was added to collected secreted protein fractions as a carrier protein to assist in the precipitation of proteins. A molecular weight standard is in the left most lane. Right: immunoblot analyses of secreted protein and whole cell lysate fractions from bacterial strains used in panel A (as indicated). The respective secreted protein fractions were diluted 20 fold prior to SDS-PAGE. (C) Left: secreted protein fractions derived from $\triangle e s c N \Delta e s c U$ double mutant strains with the indicated plasmids. Right: Immunoblot analysis of secreted protein fractions. DnaK, an abundant nonsecreted cytoplasmic protein, was used as a gel loading control (when needed) or to assess cytoplasmic contamination of secreted fractions or non-specific bacterial lysis. All samples were diluted 20 fold as in panel B. All experiments within the panels were performed twice and representative images are shown. 
[36]. These include EspA (predicted molecular mass of $20.5 \mathrm{kDa}$, filamentous translocon protein [37], EspB (predicted molecular mass of $33 \mathrm{kDa}$, YopD orthologue), EspD (predicted molecular mass of $39.5 \mathrm{kDa}$, YopB orthologue) and EspC (predicted molecular mass 140 $\mathrm{kDa}$, secreted by the type $\mathrm{V}$ secretion pathway). In contrast, low amounts of Tir and other type III effectors are secreted under these conditions but can be detected using immunoblotting approaches. As expected, $\Delta e s c U$ expressing EscU-HIS restored EspA, EspB and Tir protein secretion back to wild type EPEC levels (Figure 1B). $\Delta e s c U$ expressing either EscU(N262A) or EscU(P263A) had visibly lower amounts of protein species in their respective secretory profiles, however, a notable $\sim 30 \mathrm{kDa}$ protein species was detected by Coomassie staining and could represent low levels of either EspB or EspD (predicted molecular masses of 33 and $39.6 \mathrm{kDa}$ respectively). Immunoblotting with anti-EspA, anti-EspB and anti-Tir antibodies demonstrated reduced levels of EspA ( 20\%), EspB ( 20\%) and Tir $(\sim 70 \%)$ from $\triangle e s c U$ bacteria expressing either EscU(N262A) or EscU(P263A) relative to EscU (as determined by densitometric analyses). Immunoblotting the whole cell lysates of these strains demonstrated equal steady state amounts of EspA, EspB and Tir were present, ruling out the possibility of intracellular protein expression differences. Immunoblotting the same whole cell lysate samples with anti-EscC and anti-EscJ antibodies revealed equal amounts of the type III secretion apparatus ring forming proteins EscC and EscJ. This latter result indicates that EscC and EscJ protein expression levels are not altered by the cleavage status of EscU.

An $\Delta e s c N \Delta e s c U$ double mutant was generated to investigate if non-specific leakage from bacterial cells was occurring (perhaps due to overexpression of EscU or multi-copy effects). In the absence of EscN, the ATPase of the EPEC T3SS, type III secretion does not occur [38]. EspA, EspB and Tir were not observed in the secreted sample from the $\Delta e s c N \Delta e s c U$ double mutant by Coomassie staining (Figure 1C). Immunoblotting using antibodies against EspA, EspB and Tir did not detect these proteins in the $\Delta e s c N \Delta e s c U$ secretion fraction. Genetic complementation of $\Delta e s c N \Delta e s c U$ with plasmids expressing wild type EscN and EscU restored the secretion of EspA, EspB and Tir to wild type levels indicating that this double mutant strain could be rescued with multicopy plasmids expressing the appropriate proteins. Complementation of $\Delta e s c N \Delta e s c U$ with plasmids pJLT21, pJLT22 and pJLT23 (in the absence of pEscN) did not result in EspA, EspB and Tir secretion as assayed by Coomassie staining and immunoblotting (Figure 1C). Based on these data, the small amount of EspA, EspB and Tir in culture supernatants for $\Delta e s c U /$ pJLT22 and $\Delta e s c L /$ pJLT23 (Figure $1 \mathrm{~B}$ and $1 \mathrm{C}$ ) was due to $\operatorname{EscU}(\mathrm{N} 262 \mathrm{~A})$ or $\mathrm{EscU}(\mathrm{P} 263 \mathrm{~A})$ expression, and was EscN dependant. Importantly, plasmid mediated genetic complementation does not introduce leakage artefacts to the experimental system.

\section{The $10 \mathrm{kDa} \mathrm{EscU}$ auto-cleavage product is membrane associated}

The observation that uncleaved forms of EscU support very low levels of type III translocon and effector protein secretion was unexpected since EscU auto-cleavage has been suggested to provide a binding interface for protein substrate recognition at the base of the T3SS [26]. We therefore set out to evaluate the cleavage state of our EscU variants within sub-cellular fractions enriched for T3SS needle complexes.

To assess EscU auto-cleavage and to detect post-autocleavage products, we generated double tagged recombinant EscU forms. A hemagglutinin (HA) tag was fused to the $\mathrm{N}$ terminus and a FLAG tag was fused to the Cterminus of EscU. Using this strategy, wild type EscU auto-cleavage is predicted to produce a $29 \mathrm{kDa}$ transmembrane polypeptide that can be recognized by anti$\mathrm{HA}$ antibodies and a $10 \mathrm{kDa}$ cytoplasmic polypeptide (amino acids 263-345) that can be recognized by antiFLAG antibodies. $\Delta e s c U /$ pJLT24 (expressing HA-EscUFLAG) demonstrated a wild type EPEC secretion pattern indicating that the presence of HA and FLAG tags did not inhibit EscU function (data not shown). A sub-cellular fractionation procedure to produce a membrane fraction enriched for T3SS needle complexes [39] was then used to evaluate the double tagged protein constructs in the escU null mutant. The membrane preparation derived from $\Delta e s c U /$ pJLT24 was probed with antiHA antibodies and anti-FLAG antibodies which detected 29 and $10 \mathrm{kDa}$ polypeptide species respectively (Figure 2). These polypeptide species are in complete agreement with the predicted sizes of EscU auto-cleavage products. No full-length EscU (39 kDa) was detected in the $\Delta e s c U / \mathrm{pJLT} 24$ membrane fraction, suggesting complete auto-cleavage had occurred under these conditions. EscU(N262A) was detected exclusively at $39 \mathrm{kDa}$ with anti-HA antibodies. Interestingly, EscU(P263A) appeared as a $39 \mathrm{kDa}$ polypeptide along with a $29 \mathrm{kDa}$ and 10 $\mathrm{kDa}$ polypeptides detected by anti-HA antibodies and anti-FLAG antibodies respectively. These data demonstrate that the EscU 29 and10 kDa auto-cleavage products localized to membrane fractions enriched for T3SS needle complexes and are in agreement with the crystal structure soluble domain interactions previously reported [26]. In addition, plasmid encoded EscU (P263A) is auto-cleaved in EPEC albeit at reduced levels compared to normal EscU.

The formation of functional T3SS needle complexes is believed to be a multistep process. For EPEC, T3SS 


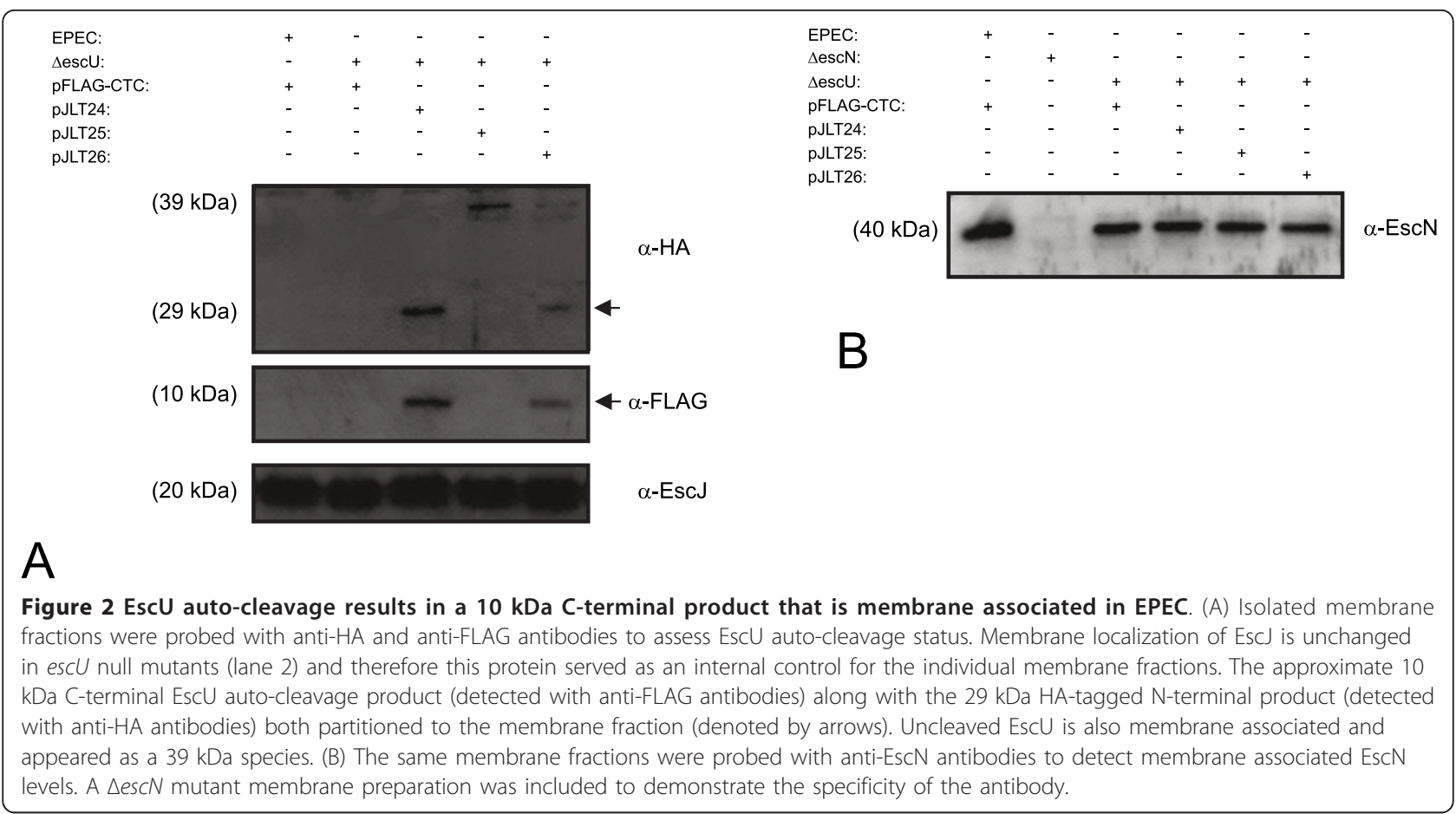

needle complexes are less well characterized than those of Salmonella and Shigella species. Purified EPEC T3SS needle complex preparations often lack certain protein components that are highly conserved in all systems and hence expected to be part of a 'complete' T3SS needle complex. For example EscF, the putative needle protein has not been detected in highly purified EPEC needle preparations [20]. Antibodies to EscJ and EscN [39] were used to probe membrane fractions to assess the expression levels of these proteins. No change in the amount of cell envelope associated EscJ or EscN was observed in $\Delta \mathrm{esc} U$ bacteria expressing any of the EscU variants (Figure $2 \mathrm{~A}$ and $2 \mathrm{~B}$ ). These data indicate that EscU auto-cleavage is not essential for EscN and EscJ localization to the cell envelope. In certain Yersinia and Shigella mutant genetic backgrounds and under defined growth conditions, the T3SS needle proteins (YscF or $\mathrm{MxiH})$ are secreted in higher amounts [30,31,40] Since no one has detected polymerized EscF (needle protein) in purified EPEC needle complexes or secreted protein fractions, we are currently unable to assess whether Esc U auto-cleavage is required for EscF polymerization or EscF protein secretion (see discussion).

\section{EscU auto-cleavage is necessary for functional} translocation of type III effector proteins into human cells The role of EscU auto-cleavage in effector injection during EPEC infection has not been evaluated. We therefore set out to evaluate the role of EscU auto-cleavage during EPEC infection of human cells. We used C- terminal HIS tagged EscU forms for these experiments as we noted the complementation efficiency for these constructs were better than the dual HA and FLAG tagged constructs (data not shown). esc $U$ mutants expressing EscU-HIS variants were tested for their ability to translocate (inject) the effector Tir into human cells. While the EPEC bundle forming pilus (BFP) is known to mediate early and initial adherence to host cells during infection, T3SS mediated Tir translocation into host cells is required for intimate EPEC adherence (mediated by a Tir/Intimin interaction). In addition, Tir translocation results in F-actin 'pedestal' structures directly beneath adherent bacteria. As expected after a three-hour infection, it was found that the $\Delta e s c U$ infection had markedly fewer bacteria intimately associated to HeLa cells (compared to the wild type infection) and could not induce host cell F-actin rearrangement (Figure 3A). Infection with $\Delta e s c U / \mathrm{pJLT} 21$ fully restored intimate adherence and F-actin pedestal structures to wild type levels, indicating that $\mathrm{Esc} U$ is required for pedestal formation. The EscU(N262A) variant encoded by $\Delta e s c U /$ pJLT22 had similar defects in intimate adherence and pedestal formation as $\Delta e s c U$ (Figure 3A). In contrast, EscU(P263A) supported an apparent increase in bacterial intimate adherence and formed short actin pedestals (see inset). Notably all strains express BFP, suggesting that the intimate adherence differences are related to T3SS and EscU function. We further quantified the number of intimately adherent bacteria by microscopic counts. These analyses revealed a significant deficiency 

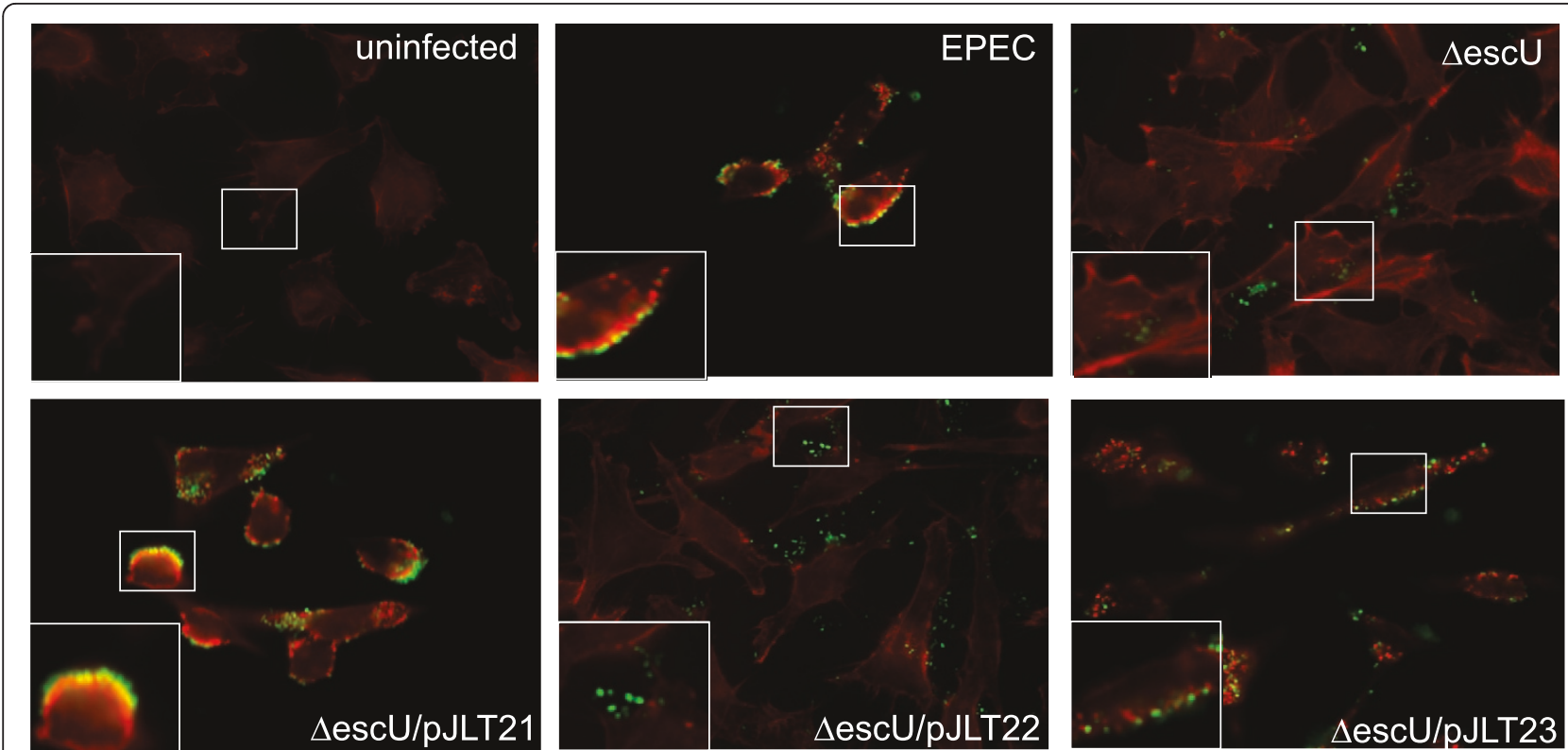

A
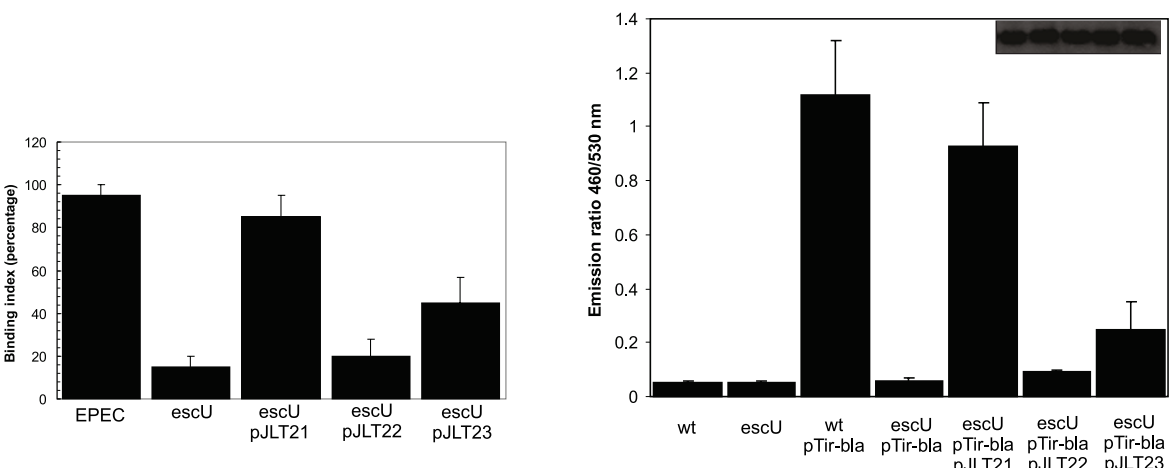

\section{B}

\section{C}

Figure $3 \mathrm{EscU}$ auto-cleavage is required for Tir translocation, actin pedestal formation and maximal intimate EPEC adherence. (A) Fluorescent microscopy images of HeLa cells following a three-hour infection with various EPEC strains. Phalloidin staining (red) was used to detect F-actin. All EPEC strains contain a plasmid that encodes GFP (green). Note the strong F-actin enrichment (red signal) within the boxed insets. This experiment was performed twice and representative merged images are shown. (B) Quantification of intimately adherent bacteria using a binding index. The bacterial binding index was defined as the percentage of cells with at least five bound bacteria that co-localized to actin pedestals. At least 50 cells were counted per sample. (C) A Tir-TEM1 effector translocation assay was used to quantify translocation levels during infection of HeLa cells. HeLa cells were infected with the indicated bacterial strains, washed twice to remove non-adherent bacteria and then loaded with the cell permeable fluorescent $\beta$-lactamase substrate CCF2/AM. Blue and green (460 and $530 \mathrm{~nm}$ ) signals were detected with a plate reader and the fluorescence ratio $(460 / 530 \mathrm{~nm})$ corrected for background is shown for the indicated strains. An immunoblot of whole cell lysates with anti-TEM1 antibodies demonstrated equivalent amounts of $\beta$-lactamase in the five strains with pTir-bla (inset). The presented translocation assay data are averages of triplicate values of the results from three independent experiments.

in intimate adherence for both the esc $U$ null mutant and escU expressing EscU(N262A) (Figure 3B).

To further support the Tir injection and actin pedestal observations, we employed a Tir-TEM-1 $\beta$-lactamase fusion protein (expressed in EPEC and $\triangle e s c U$ strains) to report on Tir translocation. This approach uses living cells loaded with a fluorescent substrate that can be cleaved by $\beta$-lactamase and has been used in EPEC/
EHEC/Citrobacter to quantitatively monitor type III effector translocation [41-45]. Using this approach, a Tir-TEM-1 fusion protein was translocated by wild type EPEC but not $\triangle e s c U$ (Figure 3C). $\Delta e s c U /$ pJLT21 demonstrated translocation of Tir-TEM-1 near wild type levels while $\Delta e s c U / \mathrm{pJLT} 23$ supported significantly less translocation albeit above $\Delta e s c U$ levels. $\Delta e s c U /$ pJLT22 was unable to support Tir-TEM1 translocation and appeared 
similar to $\Delta e s c U$. These results demonstrate that EPEC strains with auto-cleaved forms of EscU supported the translocation of Tir-TEM-1 fusion proteins into infected HeLa cells whereas strains with uncleaved EscU or the absence of EscU did not.

\section{In the absence of EscU auto-cleavage, novel Tir polypeptides are detected in culture supernatants}

The HeLa cell infection experiments established a substantial role for EscU auto-cleavage in Tir and presumably other type III effector injection by EPEC. The in vitro secretion assay experiments shown in Figure 1 reveal predominant EPEC translocon protein secretion (EspABD) and very low levels of effector proteins. In contrast, EPEC sepD mutants are known to hypersecrete abundant levels of type III effector proteins under the same growth conditions, including Tir, NleA, NleH, NleG and EspZ among others [35,39] (also see Figure $4 \mathrm{~A}$ ). We reasoned that the $\Delta$ sepD EPEC strain would be a suitable genetic background to gain some insight into the role of EscU auto-cleavage with respect to in vitro type III effector secretion. A $\triangle$ sepD $\triangle$ esc $U$ double mutant was generated and grown under secretion inducing conditions followed by collection of the secreted protein fractions. The secreted protein fraction derived from $\Delta s e p D \Delta e s c U$ was visibly lacking many protein species compared to that of $\triangle$ sepD (Figure 4A). Trans-complementation of $\Delta$ sep$D \Delta e s c U$ with pJLT21 restored secretion back to that of $\triangle$ sepD with respect to protein amounts and profile. In contrast, the $\Delta \operatorname{sepD} \Delta e s c U / \mathrm{pJLT} 22 \mathrm{did}$ not restore a $\Delta s e p D$ secretion profile. Interestingly, $\Delta$ sepD $\Delta$ escu/ pJLT23 secreted low amounts of a protein species with a similar apparent molecular mass as Tir (Figure 4A). Untagged cis-complemented sepD::escU(N262A) and sepD::escU(P263A) strains (expressing the respective esc $U$ allele from the chromosome) were generated by allelic exchange and were found to produce the same secretion profile as the respective plasmid complemented strains (Figure 4A). Immunoblotting with monoclonal anti-Tir antibodies revealed that Tir secretion occurred at variable levels when EscU or EscU variants were expressed although for EscU(N262A), a novel lower molecular weight polypeptide was detected with anti-Tir antibodies (Figure 4B). This novel polypeptide species was consistently absent from $\Delta$ sepD $\Delta$ escU/ pJLT21 or pJLT23 and the parent $\Delta s e p D$ strain.

\section{CesT membrane localization is altered in the absence of EscU auto-cleavage}

In a previous report, we have demonstrated that the multicargo type III chaperone CesT mediates effector 'docking' at the inner membrane in an EscN-dependent manner [39]. CesT is also required for Tir stability in the EPEC cytoplasm [46,47] and mediates efficient secretion of at least 9 type III effectors [39]. It has also been demonstrated that CesT contributes to effector translocation $[42,43]$. The detection of a small novel Tir polypeptide in culture supernatants derived from bacteria expressing EscU(N262A) suggested that CesT-Tir interactions may be altered in the absence of auto-cleavage. We therefore set out to investigate CesT-Tir, CesT-EscU interactions in context of EscU auto-cleavage using bacteria that expressed HA-tagged EscU variants. Total cell lysates and membrane preparations were generated from the $\triangle e s c U$ mutant expressing either EscU, EscU(N262A) or EscU(P263A) followed by SDS-PAGE and immunoblotting analyses. Total CesT levels were unchanged in all the strains, indicating that EscU auto-cleavage does not influence CesT protein expression or stability (Figure 5). As reported previously [39], CesT was detected within the membrane fraction for wild type EPEC (Figure 5). Band intensity (chemiluminescent signals) was quantified using densitometry normalized to EscJ levels within the same membrane fraction. A reduced amount of membrane associated CesT was observed for $\Delta e s c U$ and $\Delta e s c U$ expressing either EscU(N262A) or EscU(P263A), as determined by densitometric analyses. The reduced amount was statistically significant for the escU null mutant compared to wild type EPEC, although this significance did not extend to the EscU variants. Next, the membrane fractions were subjected to sucrose gradient fractionation to assess CesT membrane localization patterns. EscJ and intimin are inner and outer membrane proteins respectively and hence served to identify inner and outer membrane enriched fractions. For $\Delta e s c U$ expressing HA-EscU-FLAG, a strong enrichment of CesT was found within inner membrane fractions. In contrast, HA-EscU(262)-FLAG and HA-EscU(263)-FLAG showed a more diffuse pattern of CesT membrane association, with a considerable amount of CesT protein localizing to less dense fractions within the gradient. These observations suggested that CesT function could be altered or less efficient in the absence of EscU auto-cleavage. We therefore carried out a co-immunoprecipitation assay, using anti-CesT antibodies, to assess CesT-effector interactions. Moreover, it has been shown that $\mathrm{HpaB}$, a type III chaperone, interacts with $\mathrm{HrcU}$ [48] (EscU homologue) and hence we asked whether CesT interacts with EscU. Affinity purified anti-CesT antibodies coimmunoprecipitated equal amounts of Tir from all bacterial lysates (Figure 6). This was expected, since CesT is required for Tir stability $[46,47]$, and an earlier result that showed equal steady state levels of Tir in whole cell lysates expressing EscU variants (Figure 1). In contrast, both auto-cleaved and un-cleaved forms of EscU were not co-immunoprecipitated with anti-CesT antibodies. 

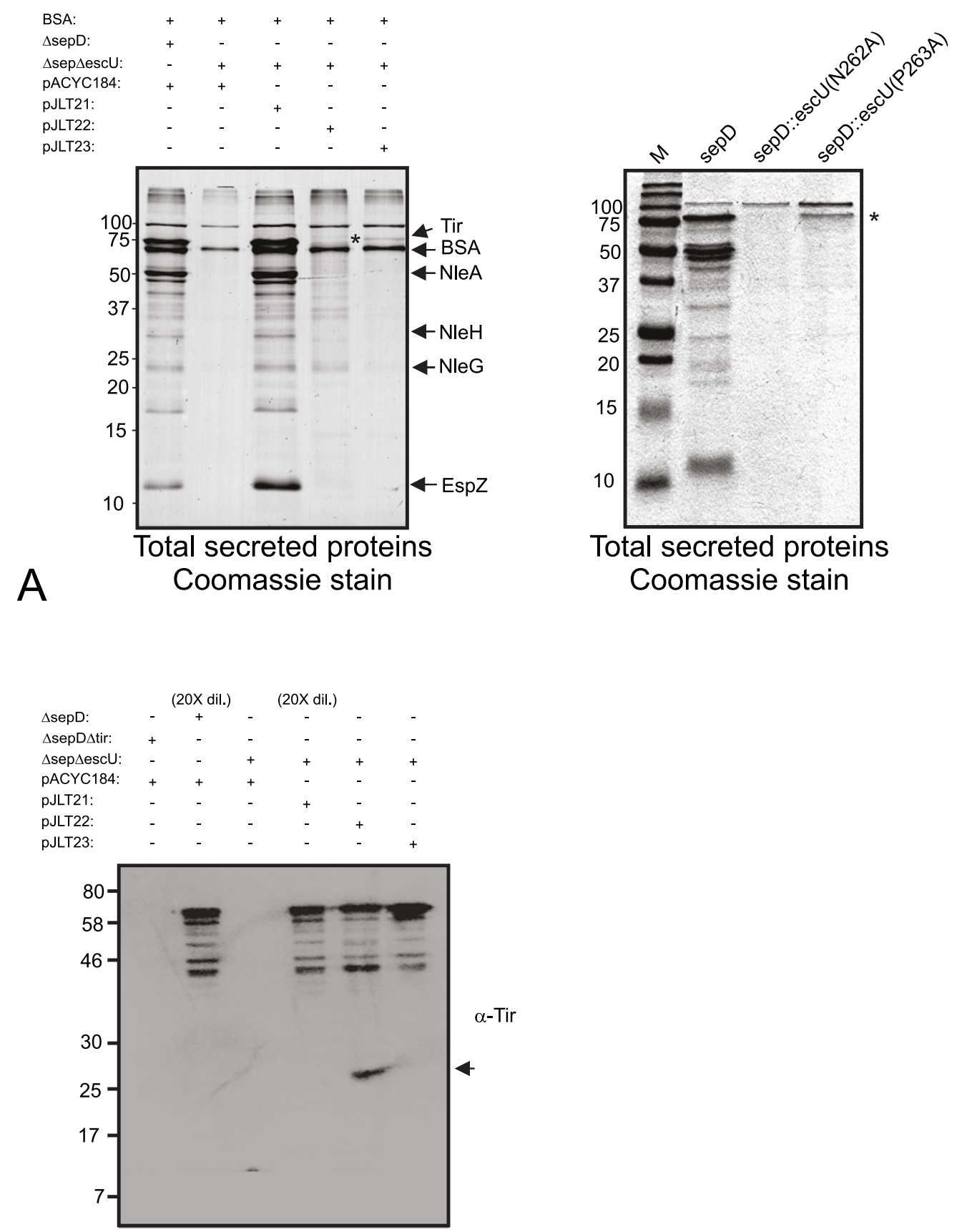

\section{B}

Figure $4 \mathrm{EscU}$ auto-cleavage is required for efficient and stable effector secretion in an EPEC $\Delta$ sepD genetic background. (A) Left: Trans-

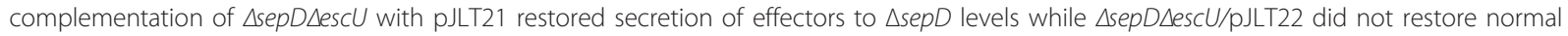
effector secretion. $\triangle$ sepDLesCU/pJLT23 secreted a protein with an apparent molecular mass similar to Tir (asterisk). The dominant effector proteins are labelled and have been previously identified using mass spectrometry analyses [35]. Purified BSA was added to collected secreted fractions and served to aid in protein precipitation. Right: genomic integration of mutant esc $U$ alleles (cis-complementation, single copy) produces the same secretion phenotypes as the plasmid trans-complemented esc U strains. Total secreted proteins were visualized by Coomassie G-250 staining. (B) Secreted protein preparations were analyzed by immunoblot with anti-Tir antibodies. Due to the abundance of secreted Tir in $\triangle s e p D$ and $\Delta s e p D \Delta e s c U / p J L T 21$, (see Coomassie stain in panel A), only these samples were diluted 20 fold for immunoblotting purposes while the others were undiluted. A $\triangle$ sepD $\Delta$ tir strain (undiluted) was included to show the specificity of the anti-Tir antibodies. Lower molecular weight protein species are therefore Tir breakdown products that were consistently observed and recognized by the anti-Tir antibodies. A novel Tir

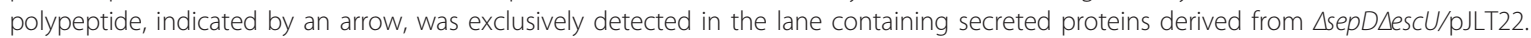




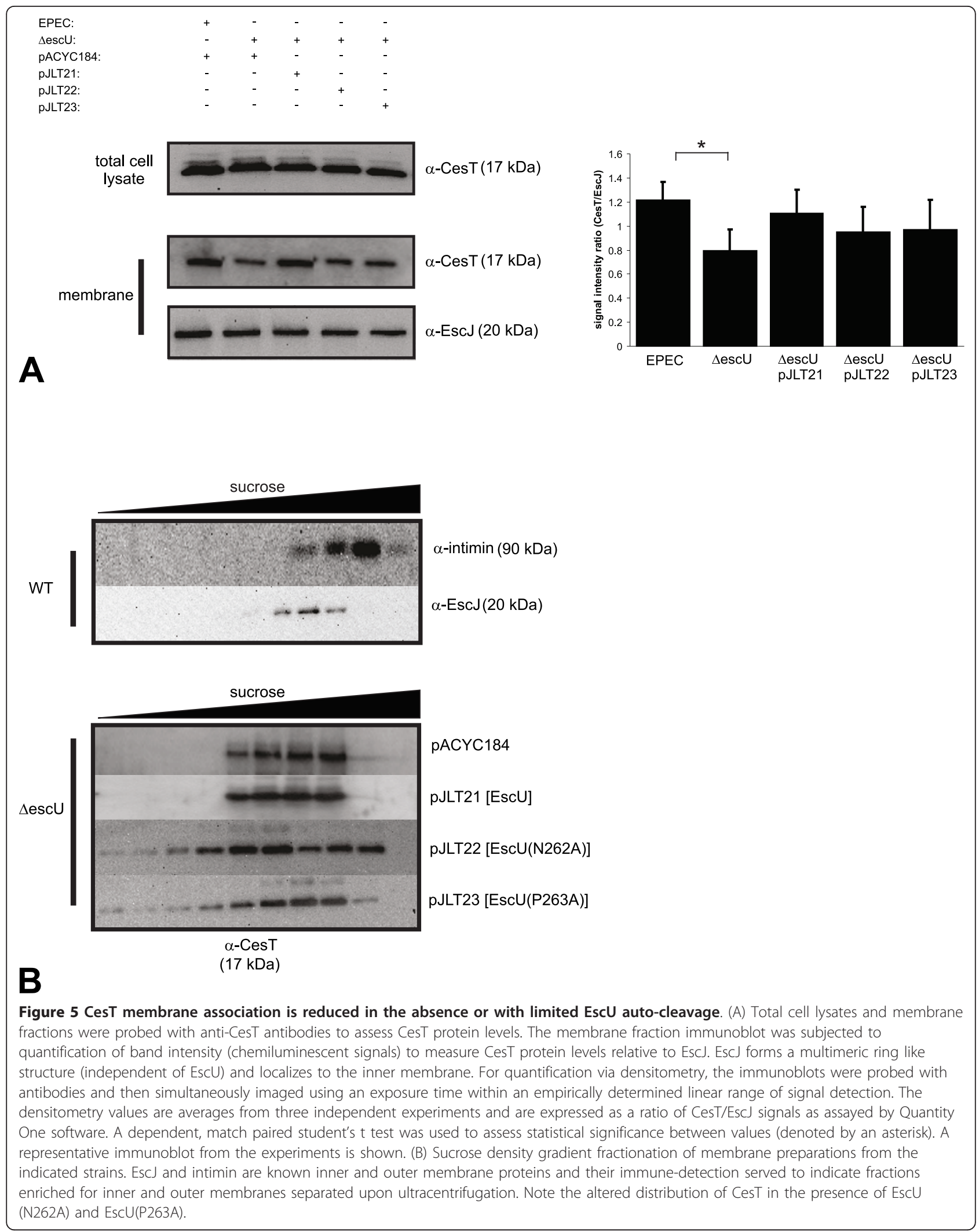




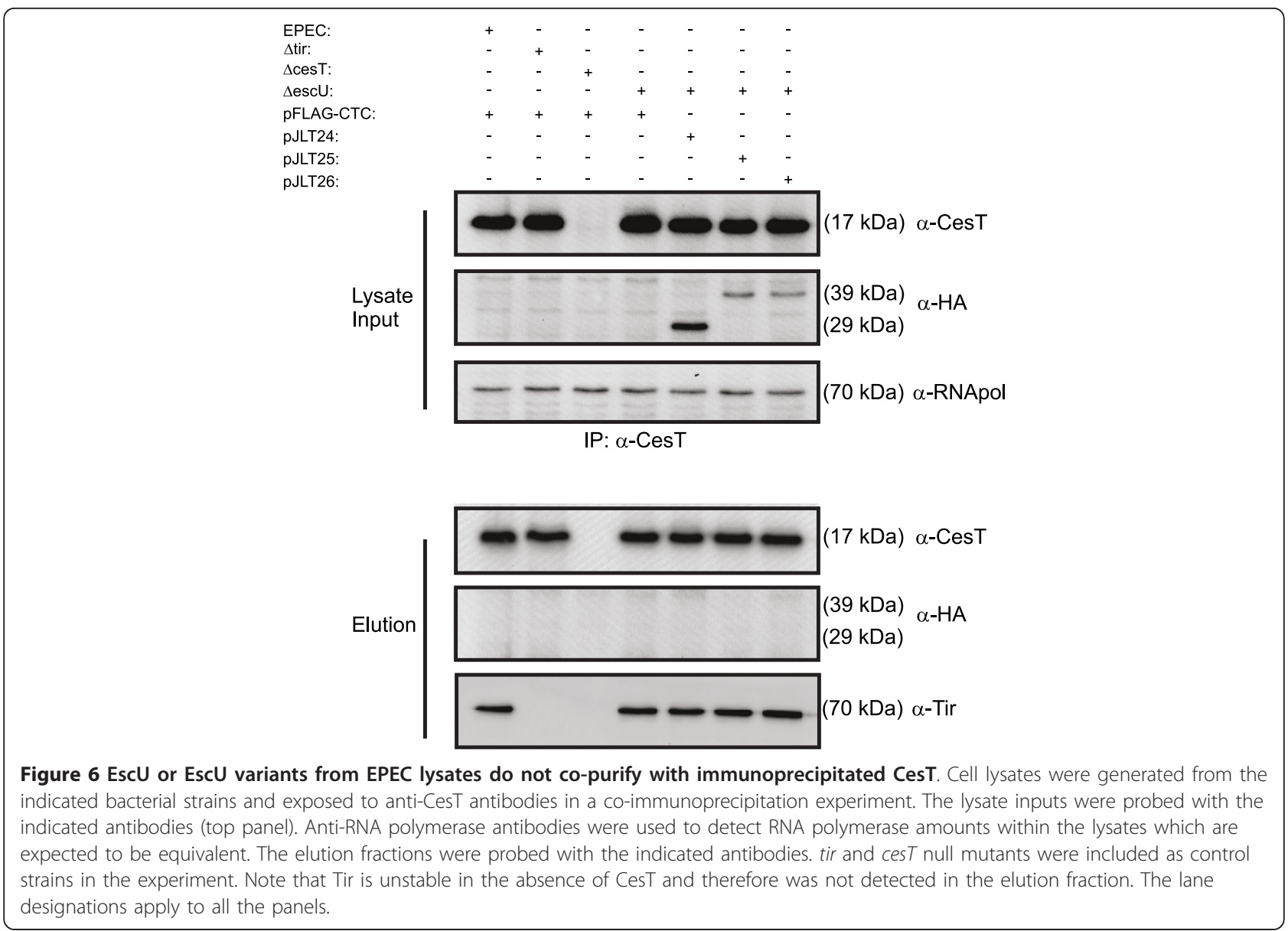

Taken together, these data indicate that total CesT membrane levels were not statistically different for EscU variant expressing strains, although the nature of CesT association with the inner membrane was altered in the absence or with limited EscU auto-cleavage. CesT retained normal effector binding function in the absence of EscU auto-cleavage and EscU did not co-immunoprecipitate with CesT.

\section{Discussion}

The T3SS is one of the most complex secretory systems in prokaryotic biology, being composed of at least 10 conserved protein components [17]. The YscU/FlhB proteins have been studied in considerable detail, although the phenotypes associated with secretion are highly variable among bacteria and even within the same species $[24,30-32,49,50]$. The intein-like auto-cleavage mechanism of EscU was previously elucidated through protein crystallography studies. It was proposed that EscU auto-cleavage likely results in an interface for important protein interactions for type III secretion. In this study, we provide evidence to suggest that EscU auto-cleavage supports efficient type III effector translocation. We also observed that the multicargo type III chaperone CesT was less efficiently associated with the inner membrane (Figure 6), which may partly explain the deficiency in type III effector translocation. The data extend previous findings pertaining to EscU auto-cleavage and suggest a critical role for EscU autocleavage in preparing the secretory apparatus to accept chaperone-effector complexes.

Previous studies have demonstrated that escU null mutants are completely deficient in secreting proteins via the T3SS pathway $[26,51]$. This phenotype holds true in other pathogens with T3SS and therefore highlights the absolute requirement of YscU/FlhB proteins in type III secretion events. Very little is known regarding how substrate proteins engage the EPEC T3SS export apparatus (EscRSTUV) located in the inner membrane. A non-cleaving EscU(N262A) variant still supported the secretion of Tir although at least one novel Tir derived polypeptide (possibly due to degradation) was linked to the uncleaved state of EscU(N262A). In contrast, bacteria expressing EscU(P263A) did not display novel Tir degradation products which suggests that its low level auto-cleavage is sufficient to support 
Tir stability and secretion. We did observe reduced levels of membrane associated CesT in the absence of EscU auto-cleavage, although the result was not statistically significant. Our efforts to further explore this observation using other approaches included separating membrane preparations by sucrose density gradients. These analyses revealed that Ces $\mathrm{T}$ membrane association is less stable without or with minimal EscU autocleavage (Figure 5B). Sucrose gradient membrane fractionation is a challenging biochemical technique, and gradient to gradient comparisons and exact gradient reproducibility are difficult. We are in the process of developing in situ approaches such as fluorescence energy transfer (FRET) to better assess protein interaction at the base of the T3SS. Nonetheless, the presented experiments provide a framework for future experiments and demonstrate that the presence of auto-cleaved EscU supported localized CesT membrane association.

Recently, Galan and co-workers reported that type III chaperones associate with a 'sorting platform' within the cytoplasm and that this chaperone association influences secretory events [52]. A platform has yet to be identified in EPEC, although it is possible that within our experimental system, CesT may be mis-localized leading to aberrant type III effector secretion. The observation of degraded Tir due to EscU(N262A) (Figure 5B) is in line with this interpretation. Furthermore, the short actin pedestals directly underneath adherent EscU(P263A) expressing bacteria which showed reduced auto-cleavage levels is consistent with this view. Since EPEC Tir injection strictly requires a EspABD translocon [53-56] and EspA filament formation requires EscF expression [57], $\mathrm{EscU}(\mathrm{P} 263 \mathrm{~A})$ likely supports the formation of a functional T3SS needle apparatus (at reduced levels) formed by the putative needle protein EscF and the translocon proteins EspA, EspB and EspD. We performed three different, yet complimentary infection assays (immunofluorescent microscopy, sub-cellular fractionation and effector $\beta$-lactamase fusions) to characterize EscU (P263A) and consistently identified intermediate effector translocation levels. Interestingly, a similar intermediate phenotype was observed for a Salmonella flhB null mutant expressing a slow cleaving $\mathrm{FlhB}(\mathrm{P} 270 \mathrm{~A})$ protein where cells were weakly motile and exported reduced amounts of flagellin [32].

Chaperone-effector complex docking at the inner membrane has been reported for many T3SS $[58,59]$. We have previously demonstrated that CesT inner membrane association is aided by the presence of the T3SS ATPase EscN [39]. The data cannot rule out the possibility that the EPEC T3SS export apparatus may be structurally impaired or malformed in the presence of uncleaved EscU although it has been demonstrated that un-cleaved forms of EscU can fold correctly [26]. The levels of EscN (T3SS ATPase) were unchanged in $\Delta e s c U$ bacteria expressing uncleaved or partially uncleaved forms of EscU (Figure 2B). Since bacteria expressing $\mathrm{EscU}(\mathrm{P} 263 \mathrm{~A})$ did support effector translocation, albeit at a reduced level, a functional T3SS export apparatus was likely assembled even though $\mathrm{EscU}(\mathrm{P} 263 \mathrm{~A})$ was only partially auto-cleaved. In support of this, within S. typhimurium, uncleaved SpaS (EscU homologue) still supported the formation of a high order export apparatus needle complex composed of at least 10 proteins as shown by blue native (BN) PAGE of enriched needle complex containing fractions [60].

A number of studies have reported on specific protein-protein interactions important for T3SS function. Auto-cleavage of $\mathrm{HrcU}$ (an EscU homologue in Xanthomonas) promoted an interaction between the ATPase $\mathrm{HrcN}$, and the C-terminal cleavage product of $\mathrm{HrcU}$ [48]. The global T3S chaperone $\mathrm{HpaB}$ was also shown to interact with $\mathrm{HrcN}$ and the full-length form of $\mathrm{HrcU}$. Co-immunoprecipitation experiments using EPEC lysates and anti-CesT antibodies failed to detect an interaction with EscU or non-cleaving EscU variants (Figure 6). Although we cannot rule out the possibility of a direct CesT-EscU interaction, we provide evidence that efficient CesT membrane association occurs when EscU is auto-cleaved (Figure 5A).

It has been demonstrated that the YscU/FlhB proteins interacts with multiple components within their respective T3SS [24,60-62]. A shortlist of protein interactions includes YscI, YscK, YscL, YscN, YscQ and YscV (using the Yersinia nomenclature) among other proteins. The putative YscL, YscI and YscQ homologues within the EPEC LEE PAI are believed to be Orf5, rOrf8 and SepQ respectively [63] although the homology scores are very low (below 15\%). A yeast two hybrid screen identified rOrf8 (putative YscI homologue) as an EscU binding partner [64]. The YscI/PrgJ family form an inner rod within the T3SS needle complex, a structure that may exist for EPEC but has not been identified in highly purified needle preparations [20]. In Shigella, Spa32 is known to interact with the C-terminal region of Spa40 [40], however in EPEC an evident Spa32 homologue has not been identified. The notable absence of clear homologues for known YscU protein partners is puzzling although might be explained by the different architecture of the EPEC T3SS compared to Salmonella, Shigella and Yersinia. Specifically, a long polymeric filament composed of EspA sits atop the EPEC needle complex [21].

From the various crystal structures now available, it has been hypothesized that the conserved auto-cleavage mechanism for the YscU/FlhB group of proteins results in a critical surface to promote protein interactions for secreted substrates [26-29]. We extend this 
interpretation with experimental data to further suggest that EscU auto-cleavage promotes translocon and effector protein secretion presumably by acting at the base of the EPEC T3SS.

\section{Conclusions}

This study provides evidence that intermediate phenotypes can be identified in the EPEC T3SS secretory pathway suggesting that sequential binding events are involved in type III effector translocation into host cells. The conserved mechanism of auto-cleavage, shown here for EscU, is a critical event that supports type III effector translocation. Additional studies will be required to identify the temporal sequence of events and to functionally characterize how protein substrates are trafficked through the T3SS.

\section{Methods}

\section{Bacterial Strains and Growth Media}

Bacterial strains generated and used in this study are listed in Table 1 . Bacterial strains were routinely cultured in Luria broth (LB) $(1 \%[\mathrm{w} / \mathrm{v}]$ tryptone, $0.5 \%[\mathrm{w} / \mathrm{v}]$ yeast extract, $1 \%[\mathrm{w} / \mathrm{v}] \mathrm{NaCl})$ at $37^{\circ} \mathrm{C}$. Antibiotics (Sigma) were added when appropriate, to a final concentration of $50 \mu \mathrm{g} / \mathrm{ml}$ kanamycin, $50 \mu \mathrm{g} / \mathrm{ml}$ streptomycin, $30 \mu \mathrm{g} / \mathrm{ml}$ chloramphenicol, $200 \mu \mathrm{g} / \mathrm{ml}$ ampicillin, $10 \mu \mathrm{g} /$ $\mathrm{ml}$ tetracycline.

\section{Isolation of Genomic and Plasmid DNA}

Genomic DNA was isolated from bacterial strains using the Purogene genomic DNA isolation kit (Gentra systems). Plasmids were isolated from bacterial strains using the QIAprep spin miniprep kit (Qiagen).

\section{Recombinant Plasmid Construction}

The escU gene was amplified via polymerase chain reaction (PCR) from EPEC genomic DNA using primers JT8 and JT10 and cloned into pET21a+ to create pETescUHIS (see table 2 for the sequences and list of primers used in this study). This construct overexpresses EscUHis from the recombinant T7 promoter. The pETescU $(\mathrm{N} 262 \mathrm{~A})_{\mathrm{HIS}}$ and $\mathrm{pETesc} U(\mathrm{P} 263 \mathrm{~A})_{\mathrm{HIS}}$ vectors were generated using the Phusion site directed mutagenesis kit (Finnzymes), following the manufacturer's directions.

Table 1 Strains and plasmids used in the study

\begin{tabular}{|c|c|c|}
\hline Strains & Description & Source/comment \\
\hline Wild type EPEC & EPEC strain E2348/69, streptomycin-resistant, BFP positive. & {$[35]$} \\
\hline $\operatorname{sescU}$ & escU deletion mutant & This study \\
\hline$\triangle s e p D$ & sepD deletion mutant & \\
\hline$\triangle \operatorname{sep} D \Delta e s c U$ & Double mutant derived from $\triangle \operatorname{sep} D$ & This study \\
\hline$\triangle \operatorname{sepD}:: \operatorname{esc} U(N 262 A)$ & Cis-complemented $\triangle \operatorname{sep} D \Delta e s c U$ strain & This study \\
\hline$\triangle \operatorname{sepD}:: \operatorname{esc} U(P 263 A)$ & Cis-complemented $\triangle$ sepD $\Delta e s c U$ strain & This study \\
\hline$\Delta \operatorname{sep} D \Delta$ tir & Double mutant derived from $\triangle \operatorname{sepD}$ & {$[35]$} \\
\hline LescNDescU & Double mutant derived from $\triangle e s c N$ & This study \\
\hline SM10גpir & E. coli strain that is permissive for pRE112 replication & \\
\hline $\mathrm{DH} 5 \alpha$ & E. coli strain used for cloning & \\
\hline DH5 $\alpha \lambda$ pir & E. coli strain used for cloning, permissive for pRE112 replication & \\
\hline \multicolumn{3}{|l|}{ Plasmids } \\
\hline $\begin{array}{l}\text { pET21 a+ } \\
\text { pACYC184 }\end{array}$ & $\begin{array}{l}\text { T7/HIS tagged fusion vector } \\
\text { Broad host range plasmid, P15A derived }\end{array}$ & $\begin{array}{l}\text { Novagen } \\
{[72]}\end{array}$ \\
\hline pETesCU HIS & pET21a+ expressing EscU-HIS & This study \\
\hline pETescU(N262A) $)_{\text {HIS }}$ & pET21a+ expressing EscU(N262A)-HIS & This study \\
\hline pETescU(P263A) $)_{\text {HIS }}$ & pET21a+ expressing EscU(P263A)-HIS & This study \\
\hline pEscN & pACYC184 expressing EscN & {$[65]$} \\
\hline pFLAG-CTC & Cloning vector to express C-terminal FLAG fusion proteins from tac promoter & Sigma \\
\hline pJLT21 & pACYC184 expressing EscU-HIS & This study \\
\hline pJLT22 & pACYC184 expressing EscU(N262A)-HIS & This study \\
\hline pJLT23 & pACYC184 expressing EscU(P263A)-HIS & This study \\
\hline pJLT24 & pFLAG-CTC backbone vector that expresses a HA-EscU-FLAG tagged protein & This study \\
\hline pJLT25 & pFLAG-CTC backbone vector that expresses a HA-EscU(N262A)-FLAG tagged protein & This study \\
\hline pJLT26 & pFLAG-CTC backbone vector that expresses a HA-EscU(P263A)-FLAG tagged protein & This study \\
\hline pRE112 & $\lambda$ pir origin, suicide vector encoding $s a c B$ & {$[73]$} \\
\hline $\mathrm{P} \triangle \mathrm{escU}$ & escU deletion fragment cloned into pRE112 suicide vector & This study \\
\hline pTir-bla & pCX341 expressing a Tir-TEM1 fusion protein & This study \\
\hline
\end{tabular}


Table 2 Primers used in this study

\begin{tabular}{|c|c|}
\hline Primer & Sequence $\left(5^{\prime}-3^{\prime}\right)$ \\
\hline HAEscU & CCGCTCGAGTACCCATACGATGTTCCAGATTACGCTATGAGTGAAAAAACAGAAAAGCCC \\
\hline EscURevBglll & GAAGATCTATAATCAAGGTCTATCGCAATACG \\
\hline JT1 & CCGAGCTCGTTACAGGATCAAACATTGCC \\
\hline JT2 & GCGCTAGCTTCACTCATTAATCATGCTCGG \\
\hline JT3 & CCGCTAGCCTTGATTATTAATCGATAATTTGC \\
\hline JT4 & GCCTCGTGGGCAATATCATTGCG \\
\hline JT7 & CCAAATGCAGTAGAACTCAGAAGGC \\
\hline JT8 & GGGGATCCCTGACATAATTGATAGATCGTTACCG \\
\hline JT10 & ACATGCATGCTCAGTGGTGGTGGTGGTGGT \\
\hline $\mathrm{JT} 12$ & /PHOS/GTTATTGTTAAAGCCCCGACTCACATT \\
\hline $\mathrm{JT} 13$ & /PHOS/GTTTGATTIITTGATGTTATTCGC \\
\hline JT14 & /PHOS/GTTAAAAACGCGACTCACATTGCG \\
\hline JT15 & /PHOS/AATAACGGTTGATTTITTGATGTTATT \\
\hline $\begin{array}{l}\text { NT278 } \\
\text { NT279 } \\
\text { NT281 } \\
\text { NT282 }\end{array}$ & $\begin{array}{l}\text { AAGGCGCCTTITAACAATAACGGTTGA } \\
\text { AAGGCGCCGACTCACATTGCGATTTGCCTA } \\
\text { GCGACTCACATTGCGATTGCCTA } \\
\text { GTITITAACAATAACGGTTGATT }\end{array}$ \\
\hline $\mathrm{XH} 1$ & CCATTAATATGTCTACAGGAGCATTAGG \\
\hline $\mathrm{XH} 2$ & CGGAATTCTCAACGAAACGTACTGGTCC \\
\hline
\end{tabular}

/PHOS/indicated primers that are $5^{\prime}$ phosphorylated, restriction sites have been underlined.

Briefly, primers pairs JT12/JT13 and JT14/JT15, that had phosphorylated 5' ends, were used to generate amplicons of pETescU(N262A $)_{\mathrm{HIS}}$ and $\mathrm{pETesc} U(\mathrm{P} 263 \mathrm{~A})_{\mathrm{HIS}}$ using pETesc $U_{\mathrm{HIS}}$ as template. The sequences of pETes$c U_{\mathrm{HIS}}, \mathrm{pETescU}(\mathrm{N} 262 \mathrm{~A})_{\mathrm{HIS}}$ and $\mathrm{pETescU}(\mathrm{P} 263 \mathrm{~A})_{\mathrm{HIS}}$ were verified using the universal $\mathrm{T} 7$ forward and reverse primers that flank the pET21a+ multiple cloning site by sequencing.

To generate pJLT21, pJLT22 and pJLT23, DNA fragments corresponding to the relevant esc $U$ allele were amplified by PCR using primers JT8 and JT10 from isolated plasmid DNA of pETesc $U_{\mathrm{HIS}}$, pETescu(N262A) $)_{\mathrm{HIS}}$ and $\mathrm{pETescU}(\mathrm{P} 262 \mathrm{~A})_{\mathrm{HIS}}$, respectively. The resulting 1.5 $\mathrm{kb}$ products were purified and treated with restriction enzymes and cloned into pACYC184 treated BamHI and SalI. To generate pJLT24, pJLT25 and pJLT26, DNA fragments corresponding to the relevant esc $U$ allele were amplified by PCR using primers HAEscU and EscURevBglII using plasmid DNA as template. The resulting PCR products were purified and sub-cloned into pFLAG-CTC vector using XhoI and BglII.

To generate pTir-bla, primers XH1 and XH2 were used to PCR amplify the tir open reading frame (without the stop codon) using EPEC genomic DNA as template. The resulting PCR product was treated with AseI and EcoRI and cloned into NdeI/EcoRI treated pCX341 (generously provided by I. Rosenshine) [43] to create pTirbla. The resulting plasmid construct was electroporated into EPEC and transformants were selected using tetracycline. Expression of Tir-TEM1 was verified by immunoblotting using anti-TEM1 antibodies (QED Biosciences).

\section{Construction of mutants in EPEC E2348/69}

A chromosomal deletion of esc $U$ was generated using allelic exchange [39]. Chromosomal DNA regions flanking the escU open reading frame were amplified from EPEC genomic DNA by PCR using primer pairs JT1/ JT2 and JT3/JT4. The resulting $0.9 \mathrm{~kb}$ and $1.2 \mathrm{~kb}$ products were treated with NheI and then combined in a 1:1 ratio followed by the addition of T4 DNA ligase. After an overnight incubation at $16^{\circ} \mathrm{C}$, an aliquot of the ligation reaction was then added to a PCR with primers JT1 and JT4 which generated a $2.1 \mathrm{~kb}$ product. The product was digested with SacI and cloned into pRE112 using E. coli $\mathrm{DH} 5 \alpha \lambda$ pir as a cloning host. The resulting plasmid $\mathrm{P} \Delta e s c U$ was verified using primers JT1 and JT4 by sequencing. P $\Delta e s c U$ was then transformed into the conjugative strain SM10 $\lambda$ pir which was then mated with EPEC E2348/69. EPEC integrants harbouring P $\Delta e s c U$ on the chromosome were selected by plating onto solid media supplemented with streptomycin and chloramphenicol. The resulting colonies were then plated onto sucrose media $(1 \%[\mathrm{w} / \mathrm{v}]$ tryptone, $0.5 \%[\mathrm{w} / \mathrm{v}]$ yeast extract, $5 \%[\mathrm{w} / \mathrm{v}]$ sucrose and $1.5 \%[\mathrm{w} / \mathrm{v}]$ agar) and incubated overnight at $30^{\circ} \mathrm{C}$. The resulting colonies were screened for sensitivity to chloramphenicol, followed by a PCR using primers JT1 and JT7 to verify deletion of the esc $U$ from the chromosome. Cis-complementation mutants were generated using the same allelic exchange 
approach using primers NT278 and NT279 for escU (N262A) and primers NT281 and NT282 for escu (P263A) genetic constructs. To generate the $\Delta e s c N \Delta e s c U$

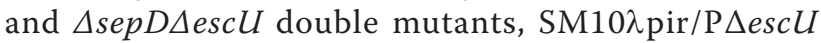
was conjugated with $\Delta e s c N$ [65], $\Delta \operatorname{sepD}$ [66] as described above. For genetic trans-complementation studies, the appropriate plasmids were transformed into electrocompetent strains followed by antibiotic selection.

\section{In vitro secretion assay}

Secretion assays were performed as previously described [39] with some minor modifications. To aid in the precipitation of proteins from secreted protein fractions, bovine serum albumin (100 ng) was added as a carrier protein during the precipitation step.

\section{Isolation of bacterial membrane fractions}

Total crude bacterial membrane preparations were generated from EPEC strains using a previously established protocol that preserves peripherally associated proteins and enriches for T3SS needle complexes [39]. Fractionation of membrane preparations was achieved using sucrose density gradients as previously described [39].

\section{Immunoprecipitation}

Immunoprecipitations with EPEC cell lysates were performed as previously described [39]. Briefly, $500 \mathrm{ng}$ of affinity purified polyclonal anti-CesT antibody was added to $50 \mu \mathrm{l}$ of Protein A conjugated agarose beads (Invitrogen) followed by washing as directed by the manufacturer. The antibody-bead mixture was blocked in phosphate buffered saline (PBS, $137 \mathrm{mM} \mathrm{NaCl}, 2.7$ $\mathrm{mM} \mathrm{KCl}, 4.3 \mathrm{mM} \mathrm{Na} \mathrm{HPO}_{4}, 1.47 \mathrm{mM} \mathrm{KH}_{2} \mathrm{PO}_{4}$ ) supplemented with $1 \%(\mathrm{w} / \mathrm{v})$ bovine serum albumin and then added to lysate preparations and incubated overnight at $4^{\circ} \mathrm{C}$ on a rotator. The samples were gently pelleted and the agarose beads were washed 3 times with PBS. The agarose beads were then exposed to $100 \mathrm{mM}$ glycine $(\mathrm{pH}$ 2.2) to elute bound proteins and neutralized with 1 $\mathrm{M}$ Tris (pH 8.8) and then prepared for SDS-PAGE.

\section{Infection of HeLa cells}

HeLa cells [American Type Culture Collection (ATCC)] were seeded onto sterile glass coverslips at a density of $1 \times 10^{5} / \mathrm{ml}$, grown for $24 \mathrm{hrs}$ and then infected with various EPEC strains at a multiplicity of infection of 50 for 3 hours. The infected HeLa cells were then prepared for microscopy as previously described [35]. Images were detected using a Zeiss Axiovert 200 inverted microscope and captured using a Hamamatsu ORCA-R2 digital camera. Microscopy based quantification of EPEC intimate adherence (binding index) was performed as previously described [67]. Briefly, GFP positive bacteria (which were identified by GFP fluorescence) that were associated with actin pedestals were quantified. At least 50 cells were examined per sample.

\section{$\beta$-lactamase reporter assays}

Type III effector-TEM1 fusion reporter assays for EPEC strains were performed as previously described [42] with minor modifications. Briefly, HeLa cells (seeded to confluence in 96 well, black, clear bottom plates [Costar 3603]) were infected with a MOI of approximately 50 for 2 hours using bacteria that had been pre-activated in DMEM $+10 \%$ FBS for 2 hours at $37^{\circ} \mathrm{C}, 5 \% \mathrm{CO}_{2}$. After 1 hour of infection, IPTG was added to a final concentration of $0.5 \mathrm{mM}$. The infected cells were gently washed twice with DMEM and then loaded with CCF2/AM using a Toxblazer kit (Invitrogen). The 96 well plate was incubated for $90 \mathrm{~min}$ in the dark and then placed in a Victor X plate reader (Perkin Elmer) set to read fluorescence using an excitation filter for $405 \mathrm{~nm}$ and emission filters for $460 \mathrm{~nm}$ (blue signal)/530 nm (green signal). Blue/green signal ratios and statistical significance (two sided Student's t test) were calculated as previously described [42]. The presented data are mean values of the results from three experiments.

\section{Protein electrophoresis and Immunoblotting}

All protein samples were separated by SDS-PAGE as described [68]. Separated polypeptides were visualized by Coomassie G-250 blue staining or Sypro Ruby Red (Bio-Rad, according to manufacturers directions). Prestained Broad Range Protein Markers (New England Biolabs, cat. \# 7708) were used for standards. For immunoblotting, separated polypeptides were transferred to Immobilon-P membrane (Millipore), blocked with skim milk $(5 \%[\mathrm{w} / \mathrm{v}]$ in Tris buffered saline + Tween20 [TBS$\mathrm{T}]$ ) or BSA, and then incubated with specific antibodies at working concentrations; anti-EscJ, 1:500 [69]; antiEscN, 1/500 [39]; anti-EspB, 1:200 [70]; anti-EspA [71]; anti-intimin 1:1000 (gift from J. Leong); anti-HA, 1:5000 (gift from R. Duncan); anti-FLAG, 1:5000 (Sigma); antiDnaK, 1:5000 (Calbiochem), anti-Tir, 1:1000 [35]; antiTEM1, 1:2000 (QED Biosciences); goat anti-mouse conjugated to horse radish peroxidise (HRP), 1:5000 (Rockland immunochemicals); goat anti-rabbit conjugated to HRP, 1:5000 (Rockland immunochemicals); goat anti-rat conjugated to HRP, 1:5000. Anti-CesT polyclonal antibodies were raised in New Zealand white rabbits against a synthetic peptide (LENEHMKIEEISSSDNK) corresponding to the C-terminal region of CesT (Pacific Immunology, CA, USA, [NIH Animal Welfare Assurance Number: A4182-01]). Final bleeds were affinity purified against the peptide by the supplier and used in immunoblots at a 1:10000 dilution. Immunoblots were developed using an enhanced chemiluminescence reagent (ECL, GE Healthcare) and data captured on a 
VersaDoc 5000 MP (Bio-Rad). Densitometry measurements to evaluate band intensity from chemiluminescent signals in immunoblotting experiments were performed using Quantity One software (Bio-Rad). Immunoblots were imaged simultaneously and within exposure times that were within an empirically determined linear range of signal detection.

\section{Ethics statement}

The grant proposal supporting this research was reviewed by the Dalhousie University Ethics Officer. Ethics approval was not required as the research does not involve human subjects, primary human cell lines/ samples or animals.

\section{Acknowledgements}

The authors would like to thank members of the Thomas lab and the Department for critical reading of the manuscript. Madhulika Prasad provided valuable technical assistance with experiments. Roy Duncan graciously provided monoclonal anti-HA antibodies. This research was supported by an operating grant (MOP84472) from the Canadian Institutes of Health Research (CIHR). Infrastructure and research equipment were supported with funds provided by the Canadian Foundation for Innovation Leaders Opportunity Fund (CFI-LOF), the Dalhousie Medical Research Foundation and Dalhousie University. N.A.T is the recipient of a CIHR New Investigator Award. The funding agencies did not participate in study design; in the collection, analysis, and interpretation of data; in the writing of the manuscript; and in the decision to submit the manuscript for publication.

\section{Author details}

${ }^{1}$ Department of Microbiology and Immunology, Dalhousie University, 5850 College Street, P.O. Box 15000, Halifax, Nova Scotia, B3H 4R2 Canada. ${ }^{2}$ Department of Microbiology and Immunology, McGill University, 3775 University Street, Montreal, Quebec, H3A 2B4 Canada.

\section{Authors' contributions}

JLT performed cloning, secretion and infection assay experiments. $\mathrm{XH}$ constructed pTir-TEM1 fusions. NAT performed secretion, infection, effector translocation and sub-cellular fractionation assays. JLT and NAT designed experiments and wrote the paper. $J \mathrm{LT}, \mathrm{XH}$ and NAT have read and approved the final version of the manuscript.

Received: 10 June 2011 Accepted: 20 September 2011 Published: 20 September 2011

\section{References}

1. Goosney DL, Celli J, Kenny B, Finlay BB: Enteropathogenic Escherichia coli inhibits phagocytosis. Infect Immun 1999, 67(2):490-495.

2. Grosdent N, Maridonneau-Parini I, Sory MP, Cornelis GR: Role of Yops and adhesins in resistance of Yersinia enterocolitica to phagocytosis. Infect Immun 2002, 70(8):4165-4176.

3. Marches O, Covarelli V, Dahan S, Cougoule C, Bhatta P, Frankel G, Caron E: EspJ of enteropathogenic and enterohaemorrhagic Escherichia coli inhibits opsono-phagocytosis. Cell Microbiol 2008, 10(5):1104-1115.

4. Dong N, Liu L, Shao F: A bacterial effector targets host $\mathrm{DH}-\mathrm{PH}$ domain RhoGEFs and antagonizes macrophage phagocytosis. EMBO $\mathrm{J}$ 29(8):1363-1376.

5. Bhattacharjee RN, Park KS, Chen X, lida T, Honda T, Takeuchi O, Akira S: Translocation of VP1686 upregulates RhoB and accelerates phagocytic activity of macrophage through actin remodeling. J Microbiol Biotechnol 2008, 18(1):171-175.

6. Fu Y, Galan JE: A salmonella protein antagonizes Rac-1 and Cdc42 to mediate host-cell recovery after bacterial invasion. Nature 1999, 401(6750):293-297.
7. Szeto J, Namolovan A, Osborne SE, Coombes BK, Brumell JH: Salmonellacontaining vacuoles display centrifugal movement associated with cellto-cell transfer in epithelial cells. Infect Immun 2009, 77(3):996-1007.

8. Steele-Mortimer O, Brumell JH, Knodler LA, Meresse S, Lopez A, Finlay BB: The invasion-associated type III secretion system of Salmonella enterica serovar Typhimurium is necessary for intracellular proliferation and vacuole biogenesis in epithelial cells. Cell Microbiol 2002, 4(1):43-54.

9. Schroeder N, Henry T, de Chastellier C, Zhao W, Guilhon AA, Gorvel JP, Meresse S: The Virulence Protein SopD2 Regulates Membrane Dynamics of Salmonella-Containing Vacuoles. PLOS Pathog 6(7):e1001002.

10. Knodler LA, Winfree $S$, Drecktrah D, Ireland R, Steele-Mortimer O: Ubiquitination of the bacterial inositol phosphatase, SopB, regulates its biological activity at the plasma membrane. Cell Microbiol 2009, 11(11):1652-1670.

11. Ruchaud-Sparagano MH, Maresca M, Kenny B: Enteropathogenic Escherichia coli (EPEC) inactivate innate immune responses prior to compromising epithelial barrier function. Cell Microbiol 2007, 9(8):1909-1921.

12. Depaolo RW, Tang F, Kim I, Han M, Levin N, Ciletti N, Lin A, Anderson D, Schneewind O, Jabri B: Toll-like receptor 6 drives differentiation of tolerogenic dendritic cells and contributes to LcrV-mediated plague pathogenesis. Cell Host Microbe 2008, 4(4):350-361.

13. Kim DW, Lenzen G, Page AL, Legrain P, Sansonetti PJ, Parsot C: The Shigella flexneri effector OspG interferes with innate immune responses by targeting ubiquitin-conjugating enzymes. Proc Natl Acad Sci USA 2005 102(39):14046-14051.

14. Nobe R, Nougayrede JP, Taieb F, Bardiau M, Cassart D, Navarro-Garcia F Mainil J, Hayashi T, Oswald E: Enterohaemorrhagic Escherichia coli serogroup 0111 inhibits NF-(kappa)B-dependent innate responses in a manner independent of a type III secreted OspG orthologue. Microbiology 2009, 155(Pt 10):3214-3225.

15. Nadler C, Baruch K, Kobi S, Mills E, Haviv G, Farago M, Alkalay I, Bartfeld S, Meyer TF, Ben-Neriah Y, et al: The type III secretion effector NleE inhibits NF-kappaB activation. PLoS Pathog 6(1):e1000743.

16. Newton HJ, Pearson JS, Badea L, Kelly M, Lucas M, Holloway G, Wagstaff KM, Dunstone MA, Sloan J, Whisstock JC, et al: The type III effectors NleE and NleB from enteropathogenic E. coli and OspZ from Shigella block nuclear translocation of NF-kappaB p65. PLoS Pathog 6(5): e1000898

17. Cornelis GR: The type III secretion injectisome. Nat Rev Microbio/ 2006, 4(11):811-825

18. Schraidt O, Lefebre MD, Brunner MJ, Schmied WH, Schmidt A, Radics J, Mechtler K, Galan JE, Marlovits TC: Topology and organization of the Salmonella typhimurium type III secretion needle complex components. PLoS Pathog 6(4):e1000824.

19. Kubori T, Sukhan A, Aizawa SI, Galan JE: Molecular characterization and assembly of the needle complex of the Salmonella typhimurium type III protein secretion system. Proc Natl Acad Sci USA 2000, 97(18):10225-10230.

20. Ogino T, Ohno R, Sekiya K, Kuwae A, Matsuzawa T, Nonaka T, Fukuda H, Imajoh-Ohmi S, Abe A: Assembly of the type III secretion apparatus of enteropathogenic Escherichia coli. J Bacteriol 2006, 188(8):2801-2811.

21. Daniell SJ, Takahashi N, Wilson R, Friedberg D, Rosenshine I, Booy FP, Shaw RK, Knutton S, Frankel G, Aizawa S: The filamentous type III secretion translocon of enteropathogenic Escherichia coli. Cell Microbiol 2001, 3(12):865-871.

22. Creasey EA, Friedberg D, Shaw RK, Umanski T, Knutton S, Rosenshine Frankel G: CesAB is an enteropathogenic Escherichia coli chaperone for the type-III translocator proteins EspA and EspB. Microbiology 2003, 149(Pt 12):3639-3647.

23. Ferris HU, Furukawa Y, Minamino T, Kroetz MB, Kihara M, Namba K, Macnab RM: FlhB regulates ordered export of flagellar components via autocleavage mechanism. J Biol Chem 2005, 280(50):41236-41242.

24. Riordan KE, Schneewind O: YscU cleavage and the assembly of Yersinia type III secretion machine complexes. Mol Microbiol 2008, 68(6):1485-1501.

25. Minamino T, Macnab RM: Domain structure of Salmonella FlhB, a flagellar export component responsible for substrate specificity switching. $J$ Bacteriol 2000, 182(17):4906-4914

26. Zarivach $R$, Deng W, Vuckovic M, Felise HB, Nguyen HV, Miller SI, Finlay BB, Strynadka NC: Structural analysis of the essential self-cleaving type III secretion proteins EscU and SpaS. Nature 2008, 453(7191):124-127. 
27. Deane JE, Graham SC, Mitchell EP, Flot D, Johnson S, Lea SM: Crystal structure of Spa40, the specificity switch for the Shigella flexneri type III secretion system. Mol Microbiol 2008, 69(1):267-276.

28. Lountos GT, Austin BP, Nallamsetty S, Waugh DS: Atomic resolution structure of the cytoplasmic domain of Yersinia pestis $\mathrm{YsCU}$, a regulatory switch involved in type III secretion. Protein Sci 2009, 18(2):467-474.

29. Wiesand U, Sorg I, Amstutz M, Wagner S, van den Heuvel J, Luhrs T, Cornelis GR, Heinz DW: Structure of the type III secretion recognition protein YscU from Yersinia enterocolitica. J Mol Biol 2009, 385(3):854-866.

30. Sorg I, Wagner S, Amstutz M, Muller SA, Broz P, Lussi Y, Engel A, Cornelis GR: YscU recognizes translocators as export substrates of the Yersinia injectisome. EMBO J 2007, 26(12):3015-3024.

31. Bjornfot AC, Lavander M, Forsberg A, Wolf-Watz H: Autoproteolysis of YscU of Yersinia pseudotuberculosis is important for regulation of expression and secretion of Yop proteins. J Bacteriol 2009, 191(13):4259-4267.

32. Fraser GM, Hirano T, Ferris HU, Devgan LL, Kihara M, Macnab RM: Substrate specificity of type III flagellar protein export in Salmonella is controlled by subdomain interactions in FlhB. Mol Microbiol 2003, 48(4):1043-1057.

33. Kenjale R, Wilson J, Zenk SF, Saurya S, Picking WL, Picking WD, Blocker A: The needle component of the type III secreton of Shigella regulates the activity of the secretion apparatus. J Biol Chem 2005, 280(52):42929-42937.

34. Kenny B, Abe A, Stein M, Finlay BB: Enteropathogenic Escherichia coli protein secretion is induced in response to conditions similar to those in the gastrointestinal tract. Infect Immun 1997, 65(7):2606-2612.

35. Thomas NA, Deng W, Baker N, Puente J, Finlay BB: Hierarchical delivery of an essential host colonization factor in enteropathogenic Escherichia coli. J Biol Chem 2007, 282(40):29634-29645.

36. Kenny B, Finlay BB: Protein secretion by enteropathogenic Escherichia coli is essential for transducing signals to epithelial cells. Proc Natl Acad Sci USA 1995, 92(17):7991-7995.

37. Daniell SJ, Kocsis E, Morris E, Knutton S, Booy FP, Frankel G: 3D structure of EspA filaments from enteropathogenic Escherichia coli. Mol Microbiol 2003, 49(2):301-308.

38. Gauthier A, Puente JL, Finlay BB: Secretin of the enteropathogenic Escherichia coli type III secretion system requires components of the type III apparatus for assembly and localization. Infect Immun 2003, 71(6):3310-3319.

39. Thomas NA, Deng W, Puente JL, Frey EA, Yip CK, Strynadka NC, Finlay BB: CesT is a multi-effector chaperone and recruitment factor required for the efficient type III secretion of both LEE- and non-LEE-encoded effectors of enteropathogenic Escherichia coli. Mol Microbiol 2005, 57(6):1762-1779.

40. Botteaux A, Sani M, Kayath CA, Boekema EJ, Allaoui A: Spa32 interaction with the inner-membrane Spa40 component of the type III secretion system of Shigella flexneri is required for the control of the needle length by a molecular tape measure mechanism. Mol Microbiol 2008, 70(6):1515-1528

41. Younis R, Bingle LE, Rollauer S, Munera D, Busby SJ, Johnson S, Deane JE, Lea SM, Frankel G, Pallen MJ: SepL resembles an aberrant effector in binding to a class 1 type III secretion chaperone and carrying an $\mathrm{N}$ terminal secretion signal. J Bacteriol 192(22):6093-6098.

42. Charpentier $\mathrm{X}$, Oswald $\mathrm{E}$ : Identification of the secretion and translocation domain of the enteropathogenic and enterohemorrhagic Escherichia coli effector Cif, using TEM-1 beta-lactamase as a new fluorescence-based reporter. J Bacteriol 2004, 186(16):5486-5495.

43. Mills E, Baruch K, Charpentier X, Kobi S, Rosenshine I: Real-time analysis of effector translocation by the type III secretion system of enteropathogenic Escherichia coli. Cell Host Microbe 2008, 3(2):104-113.

44. Deng W, de Hoog CL, Yu HB, Li Y, Croxen MA, Thomas NA, Puente JL, Foster LJ, Finlay BB: A comprehensive proteomic analysis of the type III secretome of Citrobacter rodentium. J Biol Chem 2009.

45. Tobe T, Beatson SA, Taniguchi H, Abe H, Bailey CM, Fivian A, Younis R, Matthews S, Marches O, Frankel G, et al: An extensive repertoire of type III secretion effectors in Escherichia coli $\mathrm{O} 157$ and the role of lambdoid phages in their dissemination. Proc Natl Acad Sci USA 2006, 103(40):14941-14946.

46. Abe A, de Grado M, Pfuetzner RA, Sanchez-Sanmartin C, Devinney R, Puente $J$, Strynadka NC, Finlay BB: Enteropathogenic Escherichia coli translocated intimin receptor, Tir, requires a specific chaperone for stable secretion. Mol Microbiol 1999, 33(6):1162-1175.
47. Elliott SJ, Hutcheson SW, Dubois MS, Mellies JL, Wainwright LA, Batchelor M, Frankel G, Knutton S, Kaper JB: Identification of CesT, a chaperone for the type III secretion of Tir in enteropathogenic Escherichia coli. Mol Microbiol 1999, 33(6):1176-1189.

48. Lorenz C, Buttner D: Functional characterization of the type III secretion ATPase HrcN from the plant pathogen Xanthomonas campestris pv. vesicatoria. J Bacterio/ 2009, 191(5):1414-1428.

49. Edqvist PJ, Olsson J, Lavander M, Sundberg L, Forsberg A, Wolf-Watz H, Lloyd SA: YscP and YscU regulate substrate specificity of the Yersinia type III secretion system. J Bacteriol 2003, 185(7):2259-2266.

50. Wood SE, Jin J, Lloyd SA: YscP and YscU switch the substrate specificity of the Yersinia type III secretion system by regulating export of the inner rod protein Yscl. J Bacteriol 2008, 190(12):4252-4262.

51. Deng W, Puente JL, Gruenheid S, Li Y, Vallance BA, Vazquez A, Barba J, Ibarra JA, O'Donnell $P$, Metalnikov $P$, et al: Dissecting virulence: systematic and functional analyses of a pathogenicity island. Proc Natl Acad Sci USA 2004, 101(10):3597-3602.

52. Lara-Tejero M, Kato J, Wagner S, Liu X, Galan JE: A sorting platform determines the order of protein secretion in bacterial type III systems. Science 331(6021):1188-1191.

53. Delahay RM, Knutton S, Shaw RK, Hartland EL, Pallen MJ, Frankel G: The coiled-coil domain of EspA is essential for the assembly of the type III secretion translocon on the surface of enteropathogenic Escherichia coli. J Biol Chem 1999, 274(50):35969-35974.

54. Kenny B, Lai LC, Finlay BB, Donnenberg MS: EspA, a protein secreted by enteropathogenic Escherichia coli, is required to induce signals in epithelial cells. Mol Microbiol 1996, 20(2):313-323.

55. Knutton S, Rosenshine I, Pallen MJ, Nisan I, Neves BC, Bain C, Wolff C, Dougan G, Frankel G: A novel EspA-associated surface organelle of enteropathogenic Escherichia coli involved in protein translocation into epithelial cells. EMBO J 1998, 17(8):2166-2176.

56. Wolff C, Nisan I, Hanski E, Frankel G, Rosenshine I: Protein translocation into host epithelial cells by infecting enteropathogenic Escherichia coli. Mol Microbiol 1998, 28(1):143-155.

57. Wilson RK, Shaw RK, Daniell S, Knutton S, Frankel G: Role of EscF, a putative needle complex protein, in the type III protein translocation system of enteropathogenic Escherichia coli. Cell Microbiol 2001, 3(11):753-762.

58. Thomas J, Stafford GP, Hughes C: Docking of cytosolic chaperonesubstrate complexes at the membrane ATPase during flagellar type III protein export. Proc Natl Acad Sci USA 2004, 101(11):3945-3950.

59. Akeda Y, Galan JE: Chaperone release and unfolding of substrates in type III secretion. Nature 2005, 437(7060):911-915.

60. Wagner S, Konigsmaier L, Lara-Tejero M, Lefebre M, Marlovits TC, Galan JE: Organization and coordinated assembly of the type III secretion export apparatus. Proc Natl Acad Sci USA 107(41):17745-17750.

61. Botteaux A, Kayath CA, Page AL, Jouihri N, Sani M, Boekema E, Biskri L, Parsot C, Allaoui A: The 33 carboxyl terminal residues of Spa40 orchestrate the multi-step assembly process of the type III secretion needle complex in Shigella flexneri. Microbiology

62. Minamino T, MacNab RM: Interactions among components of the Salmonella flagellar export apparatus and its substrates. Mol Microbiol 2000, 35(5):1052-1064.

63. Pallen MJ, Beatson SA, Bailey CM: Bioinformatics analysis of the locus for enterocyte effacement provides novel insights into type-III secretion. BMC Microbiol 2005, 5:9.

64. Creasey EA, Delahay RM, Daniell SJ, Frankel G: Yeast two-hybrid system survey of interactions between LEE-encoded proteins of enteropathogenic Escherichia coli. Microbiology 2003, 149(Pt 8):2093-2106.

65. Gauthier A, Finlay BB: Translocated intimin receptor and its chaperone interact with ATPase of the type III secretion apparatus of enteropathogenic Escherichia coli. J Bacteriol 2003, 185(23):6747-6755.

66. Deng W, Li Y, Hardwidge PR, Frey EA, Pfuetzner RA, Lee S, Gruenheid S, Strynakda NC, Puente JL, Finlay BB: Regulation of type III secretion hierarchy of translocators and effectors in attaching and effacing bacterial pathogens. Infect Immun 2005, 73(4):2135-2146.

67. Vingadassalom D, Campellone KG, Brady MJ, Skehan B, Battle SE, Robbins D, Kapoor A, Hecht G, Snapper SB, Leong JM: Enterohemorrhagic E. coli requires N-WASP for efficient type III translocation but not for EspFUmediated actin pedestal formation. PLoS Pathog 6(8). 
68. Laemmli UK: Cleavage of structural proteins during the assembly of the head of bacteriophage T4. Nature 1970, 227(5259):680-685.

69. Yip CK, Kimbrough TG, Felise HB, Vuckovic M, Thomas NA, Pfuetzner RA, Frey EA, Finlay BB, Miller SI, Strynadka NC: Structural characterization of the molecular platform for type III secretion system assembly. Nature 2005, 435(7042):702-707.

70. Gauthier A, Robertson ML, Lowden M, Ibarra JA, Puente JL, Finlay BB: Transcriptional inhibitor of virulence factors in enteropathogenic Escherichia coli. Antimicrob Agents Chemother 2005, 49(10):4101-4109.

71. Yip CK, Finlay BB, Strynadka NC: Structural characterization of a type III secretion system filament protein in complex with its chaperone. Nat Struct Mol Biol 2005, 12(1):75-81.

72. Chang $A C$, Cohen $S N$ : Construction and characterization of amplifiable multicopy DNA cloning vehicles derived from the P15A cryptic miniplasmid. J Bacteriol 1978, 134(3):1141-1156.

73. Edwards RA, Keller LH, Schifferli DM: Improved allelic exchange vectors and their use to analyze 987P fimbria gene expression. Gene 1998, 207(2):149-157.

doi:10.1186/1471-2180-11-205

Cite this article as: Thomassin et al:: Role of EscU auto-cleavage in promoting type III effector translocation into host cells by

enteropathogenic Escherichia coli. BMC Microbiology 2011 11:205.

\section{Submit your next manuscript to BioMed Central} and take full advantage of:

- Convenient online submission

- Thorough peer review

- No space constraints or color figure charges

- Immediate publication on acceptance

- Inclusion in PubMed, CAS, Scopus and Google Scholar

- Research which is freely available for redistribution

Submit your manuscript at www.biomedcentral.com/submit 